\title{
A LATE ROMAN SPATHA
}

\author{
A N DREA VADAY ${ }^{(0)}$ E VA SZAKOS
}

\begin{abstract}
In connection with a double-edged spatha found in a late Roman grave at the archaeological site of Hegyeshalom, Holdas-szántók, we examine the possibility of Celtic or Germanic origin of the Late Imperial Pannonian swords. The different parts of the swords are taken individually as a basis for comparison, given the shape of the hilt, blade shoulder, blade length and tip, scabbard and chape. In addition to the Western and Central European territories, we also cover the Eastern, parthus influence, and also the long swords of the Sarmatian tribes living in the vicinity of Pannonia provide information on the subject of late Roman spathas. It cannot be ignored that during many occasions the Imperium Romanum faced the different weapons and fighting style of the enemies on the battlefield, to which they were forced to adapt in the hope of victory. In determining the origin of swords, it makes difficult that we can only speak of a 'pure' Roman type if the weapon is identical in every detail to either the Celtic or the Germanic swords. Complicating the subject further the fact that the ethnicity of swords cannot be determined in all cases. Even if they were acquired as booty or are subject of trade by Barbarians and vice versa by the Romans, they are placed in the typological system based on the location of the archaeological site.

After the sword discussed, it is also important to address the issue of the archaeological context the spatha was found. The deceased buried with the spatha in the Roman cemetery of Hegyeshalom, Holdas-szántók may have been a military veteran, confirmed by the fact that he was buried with his pilum, spatha and paludamentum. His onion-headed fibula suggests that after his dismissal from the military, he also held some sort of position in the community.
\end{abstract}

Keywords: Pannonia, Late Roman Imperial Period, spatha, germanic double-edged swords.

In the early decades of the last century, both Celtic and Germanic origins were raised in relation to long, straight double-edged swords of the Romans. ${ }^{1}$ It is no coincidence that in several European provinces of the Roman Empire the typical weapon of the fusing autochthonous population of late Iron Age Celtic and Germanic origin was the long double-edged sword. In addition to the financial aspects, their usual fighting style may have contributed to the fact that, when enlisted, they could take their weapons with them into the army, regardless of whether the short sword, the gladius was still in use in the Roman infantry in the Early Imperial era.

Question may arise as to whether written sources can shed light on the origins of weapons. Latin sources use different words for sword, the names ferrum, ${ }^{2}$ ensis, gladius, spatha, also sica, and even pars pro toto a mucro ${ }^{3}$ appears. Of these, sica refers to the shape of the sword, while gladius and spatha most often refer to the size of the weapon. Sometimes, however, there are exceptions. In the description of Germania at the end of the $1^{\text {st }} \mathrm{c}$. AD, Tacitus uses the word gladius for the sword of the Germans, ${ }^{4}$ adding even the 'short' adjective to the northern Germanic tribes. ${ }^{5}$ In this work, the author uses the gladius in a general sense to refer to the sword and not to the Roman weapon form. He writes in the same way when describing the invasion of Moesia, when he uses gladius for the swords of both the Roxolans and the Romans, adding that the sword of the Barbarians is praelongus while that of the Romans is levis. ${ }^{6}$ This is evidenced by the fact that the Sarmatian sword differs not only in length from the Roman gladius, but also in its use, i.e. similar to the long swords of the Far East, it is also suitable for two-handed fencing technique. It also means a formal difference; their grip is longer than the grips of one-handed swords.

The Roman military leadership was sooner or later forced to adapt to the fighting style of the

\footnotetext{
1 Coussin 1926, 226-231. The Gallic connection is still highlighted today: Bishop 2020, 5.

2 The word 'iron' is also used for the sword in several languages.

3 The point of the weapon (sword, spear).

4 Tacitus Germania 6, 2; 18, 4; 24, 2.

5 Tacitus Germania 44. 2: 'breves gladii'.

6 Tacitus Historiae I 79, 3-4: 'sed tum umido die et soluto gelu neque conti neque gladii, quos praelongos utraque manu regunt, usui... Romanus... levi gladio inermem Sarmatam... comminus fodiebat...' (highlight from us).
} 


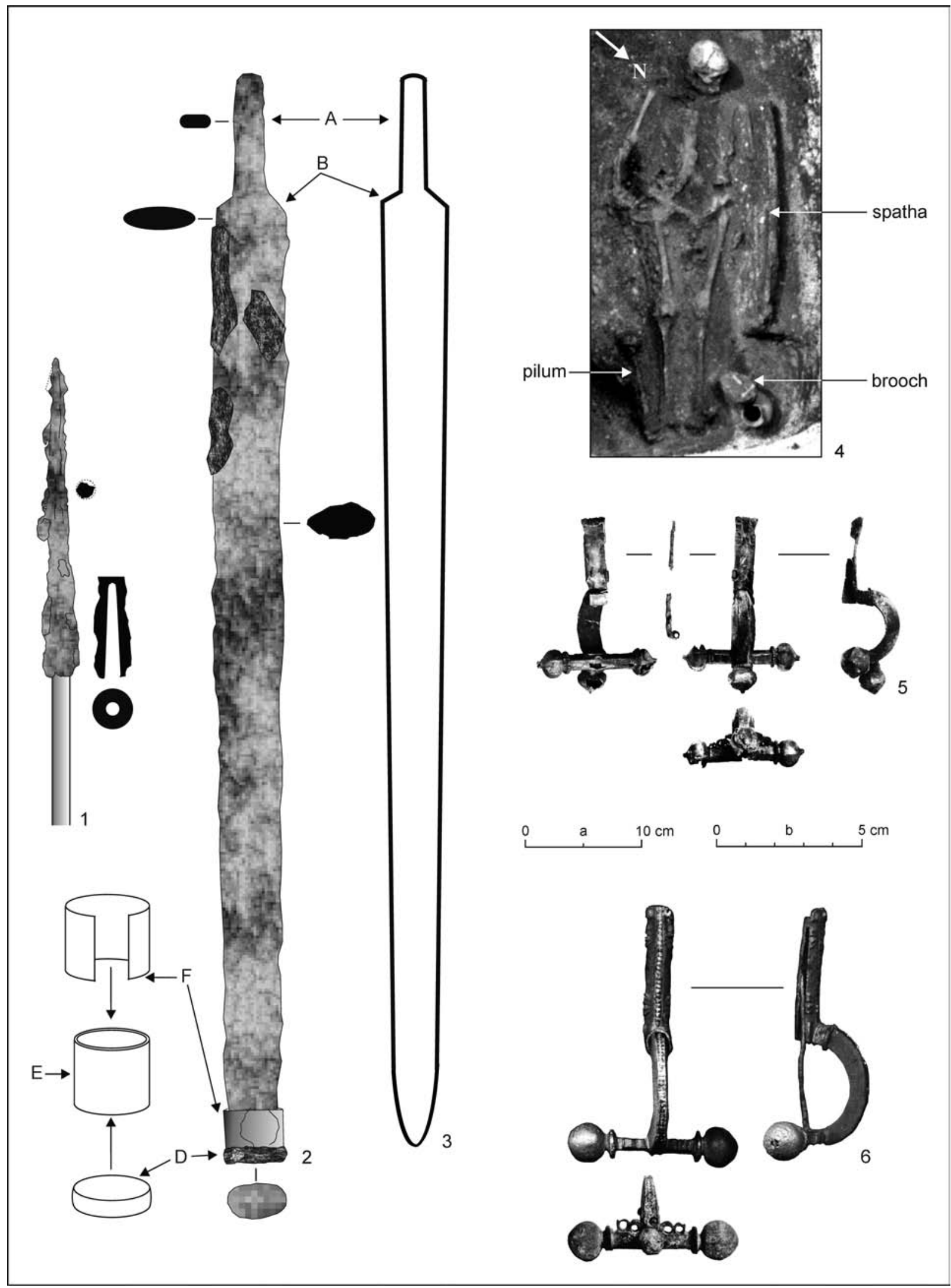

Fig. 1. Hegyeshalom. Grave 42 (75). 1-3, 5, 6 - drawing and photos A. Vaday; 4 - photo A. Figler. Scale: a -1 -3; b - 5, 6 . 
enemies, ${ }^{7}$ which also meant taking over similar types of weapons. The recurrent Parthian attacks in the East also contributed to the change, as the Roman infantry armed with a gladius on their balteus faced warriors with long swords. Joachim Werner also pointed out the Eastern influence in the armament to defend Persian tactics and weapons (Werner 1966, 137, 138). Despite the compulsion, the transition was not rapid either, the short sword, gladius, was only replaced by the long sword, the spatha in the Antonine era, which was accompanied by a change in fighting style and tactics.

Due to character limitations, we could only raise here a few necessary thoughts regarding both the origin and the change that was taking place, which is essential in relation to the late Roman spatha analysed below.

\section{THE SPATHA FROM HEGYESHALOM}

In 1996, during the construction works of the M15 motorway, András Figler carried out a rescue excavation in an archaeological site called Hegyeshalom, Holdas-szántók (Hungary). Among the 56 graves belonging to the Late Roman Imperial period cemetery, only grave 42 (75) with SW-NE orientation had two relatively intact weapon: a spatha and a pilum. In addition to the typical items of Late Roman costume and grave furniture, nine, $4^{\text {th }} \mathrm{c}$. worn or already completely illegible coins also came to light. The latest of them was an extremely worn coin of Valentinian I. dated between 350 and $378 .{ }^{8}$

The double-edged iron spatha lay on the left side of the body, parallel to the upper arm, detached, with its point toward the foot. Remains of a rusted iron scabbard are visible on the blade (Fig. 1: 2). The shoulder curves down to the blade collar. The blade here is $5.5 \mathrm{~cm}$ wide. The total length of the sword is $93.5 \mathrm{~cm}$, the width of the blade is $5 \mathrm{~cm}$ and the length of the tang is $10.3 \mathrm{~cm}$. The heavily rusty blade is only $4.3 \mathrm{~cm}$ wide above the chape. The iron chape is an oval-based cylindrical plate, with a $1.3 \mathrm{~cm}$ thick oval-shaped terminal cap with a diameter of $5 \times$
$2.8 \mathrm{~cm}$ attached to the bottom. A $3 \mathrm{~cm}$ wide bronze plate was twisted over the bottom iron plate to decorate the surface of the chape. Fine textile pieces were preserved in the rust on the top side of the sword and also the bronze plate of the chape. Since there was no human bone or any other finds nearby, it could not belong to the clothing of the dead worn at the funeral. It could not be the remnants of the material covering the feretrum either, because it was only observed at the top of the scabbard. ${ }^{9}$

A bronze fibula with onion head was found between the left ankle of the body and the longitudinal wall of the grave (Fig. 1: 6; Vaday 2019, 549). ${ }^{10}$ Its head button was hexagonal and smaller in size, ${ }^{11}$ in contrast to the pressed spherical buttons at the end of the crossbar. The original button on the head was lost at some point during use, so it was replaced with a smaller, different type of button. In doing so, the new button was no longer placed to the position of the original button, ${ }^{12}$ but was attached to the pin. However, during the repair, the pin could no longer rotate in a full arc, so it was probably only suitable for a thinner material due to its small movement, or simply pinned into the fabric. The fibula may have belonged to the cloak of the deceased, the paludamentum, which could had been laid down at the funeral next to him on the left side of the feretrum, partially covering the sword as well.

Next to the right lower leg of the dead, with its tip toward the shorter wall of the grave, the head of a corroded iron pilum was found. The socketed head with a circular cross section for the wood handle is visible $8 \mathrm{~cm}$ long on the rusty inner side. Its damaged point has the form of a deltoid. L: $27.4 \mathrm{~cm}$ (Fig. 1: 1). ${ }^{13}$

The deceased may have been a military veteran, confirmed by the fact that he was buried with his pilum, spatha and paludamentum. His onion-headed fibulas (Fig. 1: 5, 6) suggest that after his dismissal from the military, he also held some sort of position in the community. ${ }^{14}$

In recent research, the basis of different classifications of Roman swords (Biborski 1978; Biborskil Ilkjær 2006; Miks 2007) is the length of the weapon,

\footnotetext{
7 For example, against the equestrian and archer Sarmatians, Syrian archers using similar tactics were directed to Pannonia, and even the fan-shaped towers of the Roman Forts point to adaptation to the barbaric fighting style.

8 The consistency of the coin points to longer use before it was buried.

9 There were two bronze buckles in the grave from Hegyeshalom, one lying on the right leg belonging to the detached pouch, the other fastening the waist belt, it was found between the femurs. There was no archaeological find to suggest a way to suspend the scabbard.

${ }^{10}$ In the image of the fibula, the side and top view photo was taken after the restoration, the image of the head was taken before the restoration.

11 The photo was taken before the restoration, it was lost during the restoration.

12 The location of the original bulb can be easily observed in the usual place on the head side of the bow above the pin

13 A detailed report on all aspects of the finds found in the grave will be covered in the full evaluation of the cemetery.

14 In accordance with local traditions, he was laid on a feretrum on eternal rest.
} 


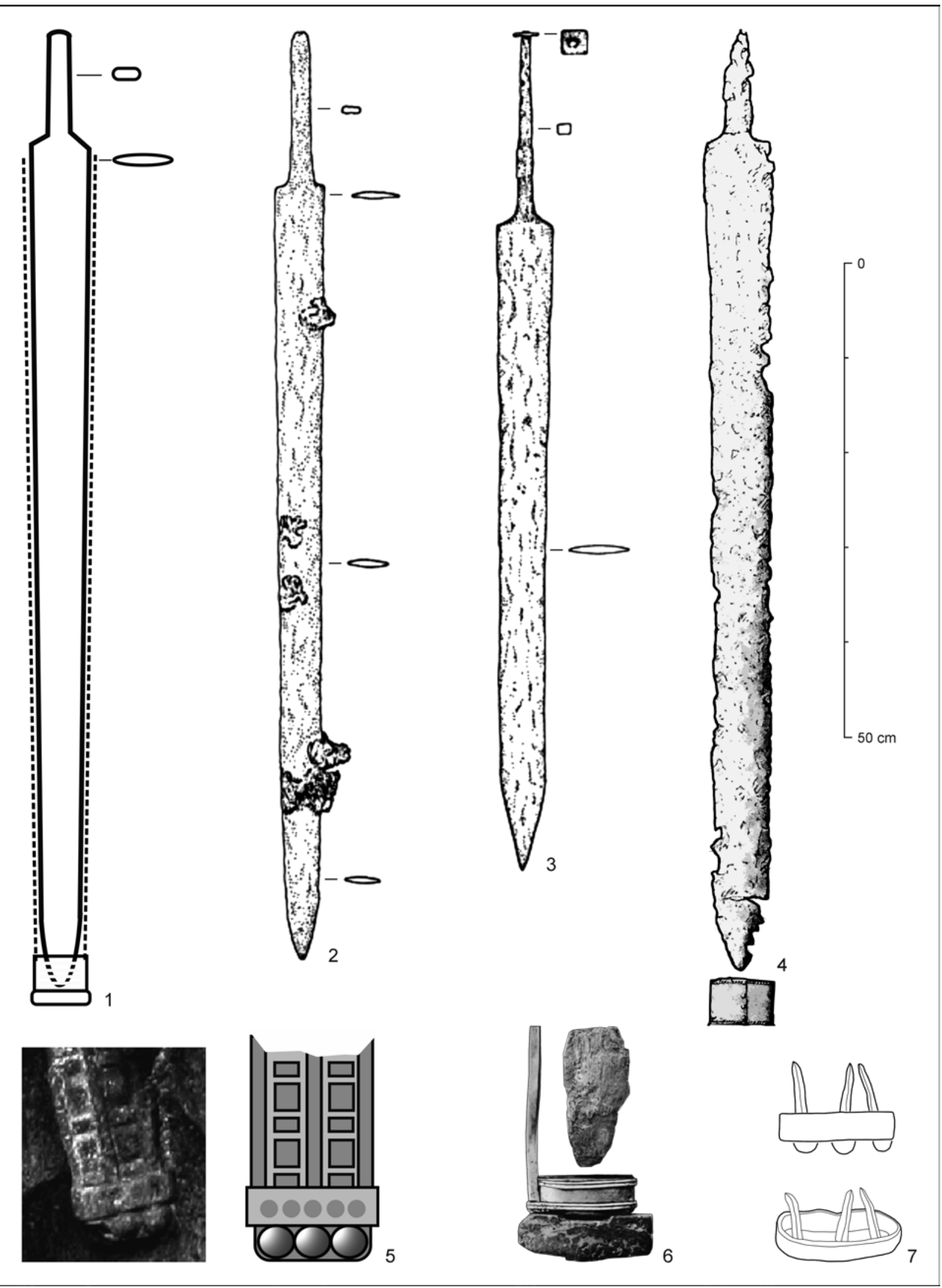

Fig. 2. Reconstruction of the sword with chape from Hegyeshalom and selected typological analogies. 1 - Hegyeshalom (drawing A. Vaday); 2, 3 - Iža (after Rajtár 1994); 4, 7 -Zalaszentgrót (after Bishop 2020; Müller 1976); 5 - detail of the sword from the Portrait of the Four Tetrarchs (drawing A. Vaday); 6-Altlußheim (after Garscha 1936). Scale: 1-4. 
which is complemented by the design of the hilt, the shoulder, the shape of the blade edge (Miks 2009, 136), the point of the blade, as well as the closure of the hilt and the shape of the cross guard. The scabbard of the sword is also characteristic, and even the way the weapon is worn with the suspension parts. Weapons were also classified based on the proportion of the parts. ${ }^{15}$

During the evaluation of the sword from Hegyeshalom there was no financial support to apply material analysis, which is also useful by defining Roman swords (Biborski et al. 1982) and the import of weapons (Biborski/Kaczanowski 1989). Moreover, due to the absence of exact parallels, it cannot be fitted into the typological systematization listed above, therefore in the search for parallels we can only rely on the characteristic features of certain parts of swords. It is no coincidence that most of these parallels come from the finds of the Carpathian Basin, an attempt to explain this will be made below.

Of the typological parallels, tangs can be divided into two types: either narrow towards the end or have parallel edges. It is worth comparing the two Antonine-era swords found in the wood-earth camp of Iža (Slovakia), a spatha and a semispatha. One has a total length of $88 \mathrm{~cm}$, of which the tang is $15 \mathrm{~cm}$ long, with a rectangular cross-section and parallel edges (Fig. 2: 2; Rajtár 1994, 83, fig. 3: 1). The other sword is $79 \mathrm{~cm}$ long, of which the tang is $18 \mathrm{~cm}$, with a square cross-section, gradually $18 \mathrm{~cm}$ towards the end of the hilt, which ends in a rivet head (Fig. 2: 3; Rajtár 1994, 85, fig. 3: 2). The $10.3 \mathrm{~cm}$ long tang of the sword from Hegyeshalom has a rectangular shape with rounded corners (Fig. 1: 2A; 2: 1). Its shape and cross-section are similar to the tang of the longer spatha in Iža (Fig. 2: 2; Rajtár 1994, 83, fig. 3: 1). The end of the blade also corresponds to this. The angled point of the shorter Iža semispatha on the other hand, is common among gladii. The sword from Cserszegtomaj, Dobogódomb (Hungary) was lost in World War II, the dimensions are unknown, only its photograph remains (Mráv 2010-2013, 55, 56, fig. 8: 14), its tang is similar to that of the semispatha in Iža, although the point of the blade is not angled, but sharply curves. The sword of the auxiliary cavalry, dated to the last quarter of the $1^{\text {st }} \mathrm{c}$., also indicates that the elements used for typology can often be mixed.
The damaged tang of the Budapest, Bécsi út (Hungary) sword was $14 \mathrm{~cm}$ long, but according to the type of sword, this could also be parallelsided, with silver plates bent on the hilt in eight rows. Based on the publication of Margit Nagy, the wooden cover of the hilt could have been $3 \mathrm{~cm}$ in diameter (Nagy 2004, 237). The hilt of the sword from Hegyeshalom may have been made of wood, but no wood remains were preserved in the rust on the tang and it had no metal plates. While the spathae from Hegyeshalom and Budapest, Bécsi út had no crossguard, the sword from the grave of Zalaszentgrót (Hungary) was reconstructed with a crossguard in its first publication (Müller 1976, fig. 12: 3). Later it was published without it (Fig. 2: 4; Bishop 2020, 20, without further number).

The heavily corroded sword from Hegyeshalom is $88.5 \mathrm{~cm}$ long, and approximately $5 \mathrm{~cm}$ wide. The cross-section of the blade thickened towards the middle, so it had no fuller. Its point is not visible due to the rusted chape, but as the blade gradually tapers at the bottom without breaking, the point may have been sharpened in a curved line (Fig. 1: 3). ${ }^{16}$

The double-edged long sword from Budapest, Bécsi út remained in fragments. According to Margit Nagy, the total length of the sword on the grave drawing was $105 \mathrm{~cm}$ including the chape, but at the time of restoration it was determined to be $95 \mathrm{~cm}$. It could not be decided due to the rust, but according to the author, it is possible that it had a fuller (Nagy 2004, 235, 237). ${ }^{17}$ The sword from Zalaszentgrót is $87.5 \mathrm{~cm}$ long, $7 \mathrm{~cm}$ wide at the rectangular blade collar, with a straight double-edged blade that gradually narrows.

Christian Miks studied the blade length of $p u-$ giones, gladii and spathae from $100 \mathrm{BC}$ to around $500 \mathrm{AD}$, the longest of which was $85 \mathrm{~cm}$ (Miks 2007, fig. 1; 2017, fig. 1). The blade of the sword from Hegyeshalom is longer than this, although the chape covers the point of the blade, but it can still be around $88 \mathrm{~cm}$. The shape (width-length) of the blade is close to the narrow Nydam/Straubing type, which has been replaced by the Illerup/Wyhl type dating from the middle of the $3^{\text {rd }} \mathrm{c}$. (Miks 2007, 99-103). The late form of this type is the Ejsbol variant, however, incorporation of the sword from Hegyeshalom into this system is difficult based on its other parts. In the second half of the $4^{\text {th }} \mathrm{c}$., double-edged swords with $5 \mathrm{~cm}$ wide blades, similar to those of Hegyeshalom,

\footnotetext{
${ }^{15}$ These aspects can only be used with intact pieces, but most of the time, due to fragmentation and rusting, it can only be done with greater safety on some of the weapons. Where the edges of the blade gradually taper to the end of the tip, the blade-totip ratio cannot be calculated.

${ }^{16}$ Reconstruction of the blade.

17 The broken part of the sword from grave 6 of the cemetery from Tiszavalk, Kenderföldek (Hungary), has been restored, so its details are now invaluable, but fortunately part of the hilt and blade has remained, where the fuller of the weapon is clearly visible (Garam/Vaday 1990, 182, fig. 11: 12).
} 
are found in the territory of Upper Elbe, Oder and Vistula, and are found in large numbers in the territory of the Przeworsk-culture (Kokowski 2003, 170-183, fig. 63). It should be noted that most of them either have crossguard or their blades gradually narrow towards the point, which makes them different in shape from the straight blade of the spatha from Hegyeshalom. ${ }^{18}$

Later in the $4^{\text {th }} \mathrm{c}$. the proportions of the swords change. The shoulders of the sword from Hegyeshalom run obliquely down into the blade. This can also be observed in Bronze Age weapons, but also occurs in the East at the Scythians and later on is also characteristic by La Tène swords. For Roman swords, oblique shoulder can also mean the survival of archaic features, especially in Hispania and Gaul (Bishop 2020, 5-7). The shoulders of the Hegyeshalom sword do not run at the same angle down into the blade and are not of the same length. (Fig. 1: 2B) Swords with similar shoulders also occur in inhumation burials dated between the end of the $3^{\text {rd }} \mathrm{c}$. and the first half of the $4^{\text {th }}$ c., e.g. Monceau-le-Neuf, grave 2, France, Lampertheim, grave III, Germany and Stockstadt, grave 1, Germany (Schulze-Dörlamm 1985, 510, 511, 514, 516, 517, fig. 2a: 6; 5: 2; 7: 3). Long, double-edged swords with asymmetrical shoulders also occur in the graves of the Late Sarmatian period of the Great Hungarian Plain, e.g. in the cemetery of the Sarmatian army protecting the Roman ramparts, Mezőszemere, Kismari Fenék, the $95 \mathrm{~cm}$ long sword of the grave 38 (Domboróczki 1997, 138, cat. 1, fig. 94; 95; Vaday/Domboróczki 2001, 18-20, 86) but the $90 \mathrm{~cm}$ long sword of the grave 42 (Vaday/Domboróczki 2001, 86, fig. 36: 2), the broken-ended weapon of the grave 58 (Vaday/Domboróczki 2001, 24-26, fig. 40; 42: 1) and the $87.6 \mathrm{~cm}$ long sword of grave 13 of the Attila-era cemetery of Alattyán, Tulát can also be listed here (Kovrig 1963, 10, 11, 193-197, pl. XLV: 15: 3; Vaday 1985, fig. 5: 11; 1988-1989, 231, cat. 3, pl. 6: 13). To continue the description of parts of the sword from Hegyeshalom, it is $5.5 \mathrm{~cm}$ wide at the top of the blade, and 2-2.5 cm lower already has a width of $6 \mathrm{~cm}$. Question arises, whether it is a matter of chance only due to rust, or was the scabbard slightly shorter than the blade. Like at the tang, there was no wood residue in the rust, so it is not possible to decide whether the scabbard was made of wood or a thin iron sheet was bent into the wood. The scabbard of the sword from Budapest, Bécsi út was assumed to be made of wood (Nagy 2004, 237, note 44). The $78.5 \mathrm{~cm}$ long scabbard of the spatha from Zalaszentgrót is also made of wood. Based on the wood remains, it can be well reconstructed that the scabbard on both sides was $0.4 \mathrm{~cm}$ wider than the blade. According to Robert Müller, 'the 4.7 and $4.5 \mathrm{~cm}$ wide strip of leather observed at 12.3 and $39.3 \mathrm{~cm}$ from the blade collar is a remnant of a leather band holding the two parts of the scabbard together' (Müller 1976, 60).

The chape of the Hegyeshalom sword is ovalbottomed, jar-like, $1.3 \mathrm{~cm}$ high, made of iron, the upper part of which is covered with a $3 \mathrm{~cm}$ wide bronze plate. In its unrestored state, the rivets are not visible at the bottom of either the bronze plate of the chape or the iron terminal cap. On the upper side of the chape plate, a fine textile was preserved in the rust.

The chape of the Budapest, Bécsi út sword was perished, it was rectangular in shape, 6 to $7 \mathrm{~cm}$ long and $5 \mathrm{~cm}$ wide, and presumably a silver plate was bent on it (Nagy 2004, 237, fig. 17: 5). Based on the in situ photograph, it could have been a plate metal chape (Nagy 2004, 237, fig. 10: 3). Margit Nagy also mentions its parallels (Nagy 2004, 251, 252).

The chape of the sword from Zalaszentgrót was made of two parts. The top was a corroded $4-4.1 \mathrm{~cm}$ wide, worn silvered bronze plate bent into an oval shape $5.9-1.9 \mathrm{~cm}$ in diameter. The two edges of the plate were decorated with punched crosses, the two ends were fastened together with four rivets, the ends of which were curved. Based on this, it can be stated that the wall of the scabbard is made of $0.5-0.7 \mathrm{~cm}$ thick wood. The scabbard was closed by a flanged iron plate that fitted exactly to the former plate. Three $4.6 \mathrm{~cm}$ long terminal knobs with hemispherical heads and rectangular cross-section were fixed to the bottom (Fig. 2: 7; Müller 1976, fig. 11: $4 a, b, 5 a, b)$. It is important to note that there is no chape on the photograph made in situ of the grave (Müller 1976, fig. 8; 10).

The three chapes with the straight bottom belong to the so-called Gundremmingen type of late Roman chapes. ${ }^{19}$ The chape type was described in 1966 by Joachim Werner $(1966,139-141)$ and then supplemented by Christian Miks with the Jakuszowice variant (Miks 2007, 408-411). The latest detailed analysis of the type was done by Michael Schmauder (2018). Straight-bottomed 'Persian-type' Late Imperial chapes can be found among the Germans even before the Hunnic period (Possenti 2011, 440). These widespread (Iriarte 2006, 83, note 27), simplified, tube-shaped, straight-bottomed chapes with three rivets on the bottom according to Michel Feugére, were innovations in late Roman fabrics responsible for supplying Roman armament and armor due to their easy production (Feugére 2002, 247). Based on Christian Miks' typology (Miks 2007, 408-411), Oster-

\footnotetext{
${ }^{18}$ Gerlachsen, Schriesheim, Mainz-Kostheim, Wiesbaden, Lugi, Zelniki Wielke: Schulze-Dörlamm 1985, 565, 566, Fundliste 4.

${ }^{19}$ Based on Christian Miks' typology, they are types A809 and A780 (Miks 2007, 408-411).
} 
burken/Kemathen-type and Asiatic-type spathae are common with Gundremmingen-type chapes. Based on its occurrence with Asiatic-type sword forms, it is suggested that it could have been manufactured by a workshop in the East or outside the Empire, and in connection with its occurrence with a crossbar also an eastern workshop related to the Hun rule of the Carpathian Basin emerged (Schmauder 2018, 523, 524). Their shape is similar to the chapes of eagle-headed swords depicted on the porphyry Portrait of the Four Tetrarchs (Fig. 2: 5). The bottom of the scabbard on the long double-edged sword in the grave of the German leader of Lébény Magasmart (Hungary) was made of a thin copper plate, the surface was covered with a silver plate divided by ribs (Pusztai 1966, 103, fig. 4: 1). As an exact parallel, a chape plate of a fragmented sword found in Altlußheim (Germany) can be cited, where even an iron disc similar to the find from Hegyeshalom remained at the bottom of the chape (Fig. 2: 6; Pusztai 1966, 109, note 19, with former bibliography). The chape plate of the $5^{\text {th }} \mathrm{c}$. Altlußheim grave was considered to be of Eastern origin (Garscha 1936, 193, pl. 40: lb-e). The dating of the chape type is between $300 \mathrm{AD}$ and the first half of the $5^{\text {th }} \mathrm{c}$. based on current finds and depictions (Miks 2015, 20; Schmauder 2018, 524).

The characteristic features of some parts of the swords may also indicate different ethnic contexts. In the case of Pannonia, in addition to the ethnic affiliation of the owner of the weapon, his social status, ${ }^{20}$ economic status ${ }^{21}$ as well as his occupation ${ }^{22}$ was assessed as an influencing factor. Nevertheless, weapons do not often occur in Early and Middle Imperial burials, which makes comparisons difficult.

The situation will not change later, weapon is also relatively rare in the Late Roman Imperial graves of Pannonia. ${ }^{23}$ This is also understandable, as weapons owned by the treasury had to be handed over to the curator fisci by the soldiers when they were dis- armed..$^{24}$ Nevertheless, albeit infrequently, weapons were placed in the graves. ${ }^{25}$ Many Barbarians were enlisted in the Roman army, so the deceased with the sword of Hegyeshalom could also be a settled German warrior, or one from the left bank of the Danube who, according to tradition, was buried with a weapon (Feugère 2002, 34, with previous opinions). This would be supported by the fact that in the Lower Elbe-Loire area, only 25 spathae are known from the graves of the $4-5^{\text {th }}$ c. (Böhme 1974, 97, note 33), however, in the Rhine-Main region the graves are characterized by offensive weapons during this period (Schulze-Dörlamm 1985, 552).

In Pannonia, the Roman-Barbarian neighbourhood dates back several centuries to the Late Imperial Era, therefore peaceful and wartime events between the two areas could have had an impact on armaments. Like in the Province, there are only a few sword graves in the early and Middle Sarmatian period of the Sarmatian Barbaricum. It can also be explained by the fact that there is no metal deposit in the Great Plain, they were forced to import iron, and the supply of weapons was difficult. In the second half of the $4^{\text {th }}$ c., however, in the Prehunnic, then in the Attila era, and later in the $5^{\text {th }} \mathrm{c}$., the situation changed when the role and importance of the military increased due to the war. Armed graves appear at Sarmatian centers, ${ }^{26}$ strategic points, river crossings, ${ }^{27}$ in border areas ${ }^{28}$ and along routes also used by the military. ${ }^{29}$

The appearance of the Huns in Europe forced many tribes to flee. The Barbarians endangered the provinces partly in Ister and partly along the Danuvius. Rome intended an important role in the Roman entrenchment defending Pannonia as an 'advanced limes'. In its construction, the Roman soldiers and the Sarmatians of Eastern origin living in the Carpathian Basin at this period worked in an alliance, the latter also taking part in the defence

\footnotetext{
${ }^{20}$ Buried are hunters or high-ranking individuals (Feugére 2002, 34, with previous opinions).

${ }^{21}$ See the carriage burials of the rich indigenous aristocracy (Ottományi 2016, 126, 192, 263, note 671, with previous literature).

${ }^{22}$ Cserszegtomaj-Dobogódomb (Mráv 2010-2013, 55, 57, 61), Sankt Georgen/Lajtaszentgyörgy, Austria (Mráv 2010-2013, 71, with the relevant literature).

${ }^{23}$ In 1972, examining $22104^{\text {th }}$ c. burials, Lányi found that only 24 burials had any weapons at all (Lányi 1972, 83).

${ }^{24}$ There have been rare individual cases where a veteran soldier has retained his weapon (Woods 1993).

${ }^{25}$ According to M. Nagy $(2004,253)$, the burial of the Budapest, Bécsi út sword, which dates back to the turn of the $4^{\text {th }}-5^{\text {th }}$ C., is explained by the fact that 'the sword was considered the property of the buried and out of respect for a military officer of presumably barbarian descent they did not comply with the provision'.

${ }^{26}$ Due to size limitations we will mention here only a few of the sword graves.

${ }^{27}$ Like the already mentioned grave 13 from Alattyán, Tulát (Vaday 1988-1989, 231, pl. 11: 19; with previous literature).

${ }^{28}$ A previous example: At Hortobágy, Poroshát (Sarmatian-Germanic border) $4^{\text {th }}$ mound group, grave 8 , silver plate chape sword (Zoltai 1941, 285, pl. VI: 38, 39a, b). There are several Germanic objects at the site, so it is quite difficult to decide whether the weapon is of Eastern origin or whether the sword came from the Germans to its owner.

${ }^{29}$ Sándorfalva, Eperjes, grave 5 (Vörös 1982-1983, 142, 143, fig. 9). Long double-edged sword with a straight iron strap chape.
} 
of the entrenchment. With this in mind, it is also important to draw attention to the chapes in the Barbaricum of the Carpathian Basin. In the cemeteries of the army protecting the entrenchment, the simpler chape of the sword of grave 38 from Mezőszemere, Kismari-Fenék (Vaday/Domboróczki 2001, fig. 29: 4) and the swords of grave 34 from Tiszadob-Sziget (Istvánovits 1993, fig. 16: 4), also refer to the possible eastern connection system regarding the chape.

Within the middle line of the entrenchment intersecting the former line of the ditch - a group of graves of barbarian military families protecting the ditch was found in Mezőszemere, KismariFenék (Hungary). In grave 38, on the left side of the skeleton, between the body and the arm, a $95 \mathrm{~cm}$ long, $5 \mathrm{~cm}$ wide-bladed sword was laid with a narrow, straight-bottomed, oval-based chape attached to the wooden scabbard with two nails (Vaday/ Domboróczki 2001, 20, fig. 27; 29: 1, 4). In the same site, at grave 42 , a detached sword with a $77 \mathrm{~cm}$ long blade and a $13 \mathrm{~cm}$ long hilt (Vaday/Domboróczki 2001, 24, fig. 36: 2), to which a 'magical bead also belonged' (Vaday/Domboróczki 2001, 23, 24, fig. 37) was also placed to the left of the body. In grave 58 , the sword was placed on the left of the body, partly on his arm, partly on his thigh, its $8 \mathrm{~cm}$ long broken tang remained, and only a $59 \mathrm{~cm}$ long piece of the blade was preserved (Vaday/Domboróczki 2001, 14-25, fig. 42: 1). Tiszavalk (Hungary) is also located inside the entrenchment. Here in grave 6 a long sword was laid on the left of the dead. The scabbard and hilt cover were made of wood. The hilt of the ritually bent and broken sword ${ }^{30}$ is $6 \mathrm{~cm}$ long, the length of the blade is $68.7 \mathrm{~cm}$, the width is $5.2 \mathrm{~cm}$ (Garam/Vaday 1990, 182, 188, fig. 10: 1; 11: 12). A so-called 'magical bead' hung from both the Mezőszemere and the Tiszavalk swords. Outside the Roman entrenchment, already in the Germanic settlement area at Tiszadob Sziget (Hungary), in the grave 34, on the left side of the body a long sword with a fuller and an iron chape was laid, which is more common among the Germans and less common among the Sarmatians (Istvánovits 1993, 110, fig. 16: 4). ${ }^{31}$

It is also clear from the listed swords that in the Provinces of the Roman Empire the form of weapons was influenced partly by the weapons of the Celtic and Germanic autochthon population, and partly by the weapons of the Germans, Sarmatians and other settled Barbarians living in the neighbourhood provinces. The fighting and fencing techniques of different ethnic groups could also influence the shape and size of swords. By the Late Imperial era, Celtic elements had already been incorporated and became Roman, but Germanic features were constantly present. In addition to these, the Eastern, Persian influence may also be taken into account regarding Late Roman spathae.

\section{BIBLIOGRAPHY}

Biborski 1978 - M. Biborski: Miecze z okresu wplywów rzymskich na obszarze kultury przeworskiej. Materiaty Archeologiczne 18, 1978, 53-165.

Biborski et al. 1982 - M. Biborski/P. Kaczanowski/Z. Kędzierski/J. Stępiński: Metallographische Untersuchungen als Kriterium einer Identifikation römischer Schwerter. In: J. Piaskowski/M. Biborski (eds.): Ancient Iron Manufactures Centres in Northern Central Europe. Archaeologia Interregionalis 3. Warszawa - Krakow 1982, 65-98.

Biborski/Ilkjær 2006 - M. Biborski/J. Ilkjær: Illerup Ådal 11-12. Die Schwerter und die Schwertscheiden. 11. Textband. 12. Katalog, Tafeln und Fundlisten. Jutland Archaeological Society Publications 25. Århus 2006.

Biborski/Kaczanowski 1989 - M. Biborski/P. Kaczanowski: Zur Identifizierung römischer Schwertimporte im Lichte metallographischer Untersuchungen, In: R. Pleiner (ed.): Archaeometallurgy of Iron. International Symposium of the Comité pour la sidérurgie ancienne de l'UISPP. Liblice, 5-9 October 1987. Prague 1989, 379-385.

Bishop 2020 - M. C. Bishop: The Spatha. The Roman Long Sword. Bloomsbury 2020.
Böhme 1974 - H. W. Böhme: Germanische Grabfunde des 4. bis 5. Jahrhunderts zwischen unterer Elbe und Loire. Studien zur Chronologie und Bevölkerungsgeschichte. Münchner Beiträge zur Vor- und Frühgeschichte 19. München 1974.

Couissin 1926 - P. Couissin: Les armes romains. Essai sur les origines et l'évaluation des armes individuélles du légionnaire romain. Paris 1926.

Domboróczki 1997- L. Domboróczki: Mezőszemere - Kismari-Fenék. In: P. Raczky/T. Kovács/A. Anders (szrek. eds.): Utak a múltba. Az M3-as autopálya régészeti leletmentései - Paths into the past. Rescue excavations on the M3 motorway. Budapest 1997, 99-102, 186, 187.

Feugère 2002 - M. Feugère: Weapons of the Romans. Stroud Charleston 2002.

Garam/Vaday 1990 - É. Garam/A. Vaday: Sarmatische Siedlung und Begräbnisstätte in Tiszavalk. Communicationes Archaeologicae Hungariae 1990, 171-219.

Garscha 1936 - F. Garscha: Das völkerwanderungszeitliche Fürstengrab von Altlußheim. Germania 20, 1936, 191-197.

\footnotetext{
${ }^{30}$ Damage to the weapon was not a custom among the Romans, but it was a common phenomenon in both late La Tène and Germanic cremation graves.

${ }^{31}$ Fig. 16: 1 depicts a central fuller in a section, but on the other side of the very rusty weapon, it is not visible.
} 
Iriarte 2006 - A. Iriarte: De reconstructie van de militaire uitrusting. In: J. H. Pouls/H. J. G. Crompvoets (eds.): De Gouden Helm uit de Peel. Congres over de Gouden Helm uit de Peel op 25 maart 2006. Meijel 2006, 79-90.

Istvánovits 1993 - E. Istvánovits: Das Gräberfeld aus dem 4. -5. Jahrhundert von Tiszadob-Sziget. Acta Archaeologica Academiae Scientiarum Hungaricae 45, 1993, 91-146.

Kokowski 2003 - A. Kokowski: Die Przeworsk-Kultur. Ein Völkerband zwischen 200 vor Chr. und 375 nach Chr. In: A. Kokowski/C. Leiber (Hrsg.): Die Vandalen. Die Könige. Die Eliten. Die Krieger. Die Handwerker. Publikation zur Ausstellung "Die Vandalen“. Ausstellung im Weserrenaissance-Schloss Bevern vom 29. März bis 26. Oktober 2003. Nordstemmen 2003, 77-183.

Kovrig 1963 - I. Kovrig: Das awarenzeitliche Gräberfeld von Alattyán. Archaeologia Hungarica N. S. 40. Budapest 1963.

Lányi 1972 - V. Lányi: Die spätantiken Gräberfelder in Pannonien. Acta Archaeologica Academiae Scientiarum Hungaricae 24, 1972, 53-213.

Miks 2007 - Chr. Miks: Studien zur römischen Schwertbewaffnung in der Kaiserzeit. Kölner Studien zur Archäologie der römischen Provinzen. Band 8. Rahden/ Westf. 2007.

Miks 2009 - Chr. Miks: Ein römisches Schwert mit Ringknaufgriff aus dem Rhein bei Mainz. Mainzer Archäologische Zeitschrift 8, 2009, 129-165.

Miks 2015 - Chr. Miks: Sword, gladius. In: The Encyclopedia of the Roman Army. Chicheste - Malden, MA, 2015. DOI: https://doi.org/10.1002/9781118318140.wbra1463

Mráv 2010-2013 - Zs. Mráv: The Roman Army along the Amber Road between Poetovio and Carnuntum in the $1{ }^{\text {st }}$ Century A.D. - Archaeological evidence. A preliminary research report. Communicationes Archaeologicae Hungariae 2010-2013, 49-100.

Müller 1976 - R. Müller: Római kori leletek Zalaszentgrótról. Zalai Gyüjtemény 6, 1976, 33-68.

Nagy 2004 - M. Nagy: Két késő római kori fegyveres sír az aquincumi canabae nyugati szélén. Budapest Régiségei 38, 2004, 231-315.

Ottományi 2016 - K. Ottományi: A budaörsi római vicus temetője. In: K. Ottományi (szerk.): A budaörsi római vicus temetője. Régészeti tanulmányok. Budapest 2016, 9-372.

Possenti 2011 - E. Possenti: Una tomba di cavaliere della metà del V secolo da Arzignano (Vicenza). Archeologia Medievale 38, 2011, 431-457.

Pusztai 1966 - R. Pusztai: A lébényi germán fejedelmi sír. Arrabona 8, 1966, 99-118.

Manuscript accepted 7. 6. 2021

Translated by Eva Szakos

Andrea Vaday DSc, Prof.

University of Pécs

Department of Archaeology

Rókus utca 2. 'M' épület I. emelet

$\mathrm{H}-7624$ Pécs

vaday54@gmail.com
Rajtár 1994 - J. Rajtár: Waffen und Ausrüstungsteile aus dem Holz-Erde-Lager von Iža. Journal of Roman Military Equipment Studies 5, 1994, 83-95.

Schmauder 2018 - M. Schmauder: Ein spätrömischer Ortbandabschluss? Zu einem exzeptionellen Objekt aus der Sammlung Langfeld. In: M. Aufleger/P. Tutlies (Hrsg.): Das Ganze ist mehr als die Summe seiner Teile. Festschrift für Jürgen Kunow anlässlich seines Eintritts in den Ruhestand. Materialien zur Bodendenkmalpflege im Rheinland 27. Bonn 2018, 521-528.

Schulze-Dörlamm 1985 - M. Schulze-Dörlamm: Germanische Kriegergräber mit Schwertbeigabe in Mitteleuropa aus dem späten 3. Jahrhundert und der ersten Hälfte des 4. Jahrhunderts n. Chr. Jahrbuch des Römisch-Germanischen Zentralmuseums Mainz 32, 1985, 509-569.

Tacitus Germania - Cornelius Tacitus: Germania Agricola Dialogus de oratoribus. Ed. E. Koestermann. Lipsiae 1962.

Tacitus Historiae - Cornelius Tacitus: Historiarum libri. Ed. E. Koestermann. Lipsiae 1961.

Vaday 1985 - A. Vaday: Sarmatisches Gräberfeld in Törökszentmiklós-Surján-Újtelep. Acta Archaeologica Academiae Scientiarum Hungaricae 37, 1985, 345-390.

Vaday 1988-1989 - A. Vaday: Die sarmatischen Denkmäler des Komitats Szolnok. Ein Beitrag zur Archäologie und Geschichte des sarmatischen Barbaricums. Antaeus 17-18, 1988-1989, 9-159.

Vaday 2019 - A. Vaday: Angaben zur Rekonstruktion der Leichenbetten. In: G. I. Farkas/R. Neményi/M. Szabó (eds.): Visy 75. Artificem commendat opus. Studia in honorem Zsolt Visy. Pécs 2019, 547-557.

Vaday/Domboróczki 2001- A. Vaday/L. Domboróczki: Mezőszemere, Kismari-fenék. Spätkaiser-frühvölkerwanderungszeitliches Gräberfeldsdetail. Agria 37, 2001, 5-206.

Vörös 1982-1983 - G. Vörös: Hunkori szarmata temető Sándorfalva-Eperjesen. Móra Ferenc Múzeum Évkönyve 1, 1982-1983, 129-172.

Werner 1966 - J. Werner: Spätrömische Schwertortbänder vom Typ Gundremmingen. Bayerische Vorgeschichtsblätter 31, 1966, 134-141.

Woods 1993 - D. Woods: The ownership and disposal of military equipment in the Late Roman army. Journal of Roman Military Equipment Studies 4, 1993, 55-65.

Zoltai 1941 - L. Zoltai: Die Hügelgräber der römischen Kaiserzeit in Hortobágy. Laureae Aquincenses. Memoriae Valentini Kuzsinszky dicatae II. Aquincumi babérágak, Kuzsinszky Bálint emlékének szenteli Budapest-székesfövárosközönsége és a Pázmány-Egyetem Érem-és Régiségtani Intézete. Dissertationes Pannonicae. Ser. II. Fasc. 11. Budapest 1941, 269-308.
Eva Szakos

Castle Headquarters Integrated Regional Development Centre Department of Archaeology

Szent Mihály u. 4

$\mathrm{H}-6721$ Szeged

evi.szakos@gmail.com 
